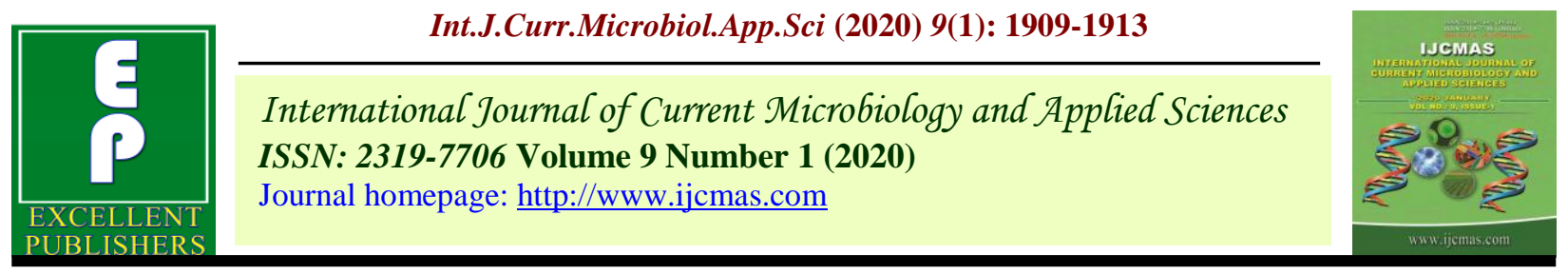

Original Research Article

https://doi.org/10.20546/ijcmas.2020.901.213

\title{
Evaluation of Front Line Demonstration Trials on Clusterbean in Nagaur District of Rajasthan, India
}

\author{
Sumitra Devi Bamboriya ${ }^{1}$, Gopichand Singh ${ }^{1}$, Arjun Singh Jat ${ }^{1}$ and S. Ishwar Singh \\ ${ }^{1}$ Krishi Vigyan Kendra, Maulasar, Nagaur-II, District-Nagaur, Rajasthan, India \\ ${ }^{2}$ Agriculture University, Jodhpur Rajasthan, India \\ *Corresponding author
}

\begin{tabular}{|c|}
\hline Keywords \\
\hline $\begin{array}{l}\text { Front line } \\
\text { demonstration, } \\
\text { Clusterbean, } \\
\text { Improved } \\
\text { technology, } \\
\text { Mechanized sowing }\end{array}$ \\
\hline Article Info \\
\hline $\begin{array}{l}\text { Accepted: } \\
\text { 15 December } 2019 \\
\text { Available Online: } \\
\text { 20January } 2020\end{array}$ \\
\hline
\end{tabular}

A B S T R A C T

Front Line demonstration (FLDs) is a unique approach to provide a direct interface between researcher and farmers as the scientists are directly involved in planning, execution and monitoring of the demonstrations for the technologies developed by them and get direct feedback from the farmers' field about the crops. The frontline demonstrations on clusterbean were conducted by Krishi Vigyan Kendra, Maulasar, Nagaur-II during 2018 to 2019 in kharif season in village of Dabra in Maulasar bock. All 50 demonstrations on clusterbean crop were carried out in area of 20 ha by the active participation of farmers with the objective to demonstrate the improved technologies of clusterbean production potential. The improved technologies consisting use of improved variety, seed treatment with carbendazim, mechanized sowing, integrated nutrient and weed management. The improved technology recorded $24.71 \%$ higher yield of $9.41 \mathrm{q} / \mathrm{ha}$ in demonstration plot as compared to local check (7.5 q/ha).

\section{Introduction}

Clusterbean is cultivated predominantly under semi-arid areas of tropical and subtropical regions. India is the largest producer of guar seed and accounts for around 75-80 per cent of the total guar production in the world. In India, it is grown in an area of 4.10 million hectares with a production of 1.85 million tonnes and productivity of $451 \mathrm{~kg} / \mathrm{ha}$ and is annually contributing to around $80 \%$ share to the world's total production (Agricultural Statistics at a Glance 2018). Rajasthan state accounts for 65-70 per cent of India's production. The other producers are Gujarat, Haryana, Punjab, Uttar Pradesh and Madhya Pradesh. The importance of guar has increased considerably in recent years due to the general ecological trend of utilizing polysaccharides in different industrial applications. It has high calorific and nutritive value and its seed contains $28-32 \%$ of gum 
(Kherawat et al., 2013). Unlike the seeds of other legumes, guar seeds contains sufficient amount of galactomannan gum, which is also used in the production of water proof biocide films. Guar gum is used in textile, paper manufacture, stamps, cosmetics, pharmaceuticals, oil wells, mining industries, explosives, food products, e.g. bakery products, ice cream and stabilizer in cheese making. On the other hand, guar is considered as an excellent soil improvement crop, like other legumes, with respect to available nitrogen which improve yield of succeeding crops. Due to high degree of drought and salinity tolerance, guar could be a valuable alternative crop for the exploitation of the semiarid environment, where high temperature, poor erratic rainfall and elevated soil salt content restrict the cultivation of other crops. Keeping this in view, frontline demonstrations on clusterbean was undertaken to improve the productivity and profitability of clusterbean with proven improved production technologies on farmer's fields.

\section{Materials and Methods}

To assess the economic feasibility of technology transfer for crop management and better productivity of clusterbean, the front line demonstrations were conducted on 50 farmers field of adopted village Dabra of Nagaur district in Rajasthan during kharif season of 2018 and 2019 in rainfed condition on sandy loam soil with low-medium fertility status under Pearlmillet/Greengram-Fallow cropping system. Each demonstration was conducted on an area of 0.4 ha and the same area adjacent to the demonstration plot was kept as farmer's practices. The package of improved production technologies included improved variety, fertilizer 10-15:30-40 kg NP per schedule. Seeds were treated with carbendazim @2 g/kg seed and inoculated with Rhizobium @ 10 g/kg seed. Seed sowing was done in July in every year with a seed rate of $18 \mathrm{~kg} / \mathrm{ha}$ in line sowing with row to row spacing of $30 \mathrm{~cm}$ and $10 \mathrm{~cm}$ between plants. Optimum plant population was maintained in the demonstrations. Recommended dose of fertilizer was applied through DAP as basal application. One hand weeding was done at 25-30 DAS for control of weeds. The crop was harvested during October after the leaves turn yellow and start dropping. The benefit cost ratio was calculated based on gross return. The yield data were collected from both the demonstration and farmers practice and their technology gap, extension gap and technology index were worked out Samui et al., (2000) as given below-

$\%$ increased yield $=$ Demonstration yieldfarmers yield $\times 100 /$ farmers yield

Technology gap $=$ Potential yield Demonstration yield

Extension gap = Demonstration yieldFarmers yield

Technology Index = Technology gap $\times$ 100/potential yield

\section{Results and Discussion}

The major differences were observed between demonstration package and farmer's practices regarding recommended varieties, seed treatment, sowing method, time of sowing and fertilizer dose. Table 1 shows that under the demonstrated plot only recommended varieties and bio-agents were given to farmer by the KVK and all the other package and practices were timely performed by the farmer itself under the supervision of KVK scientist. Under farmers' practice, they generally sow seed of clusterbean varieties RGC-1003/RGC-1017 at higher seed rate without seed treatment. As a result, the 
farmers selected under FLD programme on clusterbean were provided seed of clusterbean variety RGC-1038 \& RGC-1033. It is also observed that under farmer situation, normally sowing of clusterbean is earlier to escape from water shortage for irrigation, thus leading to reduction in yield. Regarding the method of fertilization, under demonstration, all fertilizers were drilled at the time of sowing, whereas, under farmers' practice, broadcast method of fertilization was adopted.

\section{Grain yield}

Results concluded that average yield $9.60 \&$ $9.22 \mathrm{q} /$ ha were found in demonstration plot of variety RGC-1038 and RGC-1033 as compared to $7.40 \& 7.70 \mathrm{q} / \mathrm{ha}$ in control plot during 2018 and 2019, respectively of the same village. This improvement in yield might be due to seed treatment, use of bio fertilizers, timely sowing, application of recommended dose of fertilizers, proper and timely weed management and integrated pest management practices.
Extension \& technology gap and technology index

The extension gap 2.20 and $1.52 \mathrm{q} \mathrm{ha}^{-1}$, technology gap 5.40 and $5.78 \mathrm{q} \mathrm{ha}^{-1}$ and technology index 36.00 and $38.56 \%$ was recorded (Table 2) during 2018-19 and 201920, respectively. The technology index showed the feasibility of evolved technology at the farmer's fields.

\section{Economics}

The net returns of demonstration plot was Rs. 20900/ \& Rs. 32474/- per ha and for control Rs. 12800/ and Rs. 25520/- per ha during 2018 and 2019, respectively. Benefit-cost ratio for demonstration and control was 2.30 and 1.96 , respectively (Table 3 ). The results indicated that the frontline demonstrations gave good impact over the farming community of Nagaur district as they were motivated by the new agricultural technologies applied in the FLD plots (Table 1). This finding is in corroboration with the findings of Patil et al., (2015) in greengram and in blackgram by Sahare et al., (2018).

Table.1 Details of gap analysis in clusterbean

\begin{tabular}{|c|c|c|}
\hline Particulars & Farmers practices & Recommended practices \\
\hline Variety & RGC-986, RGC-1017 & RGC-1038, RGC-1033 \\
\hline Seed rate $(\mathrm{kg} / \mathrm{ha})$ & $12-15$ & $15-18$ \\
\hline Seed treatment & No seed treatment & $\begin{array}{l}\text { Seed treated with carbendazim } 2 \mathrm{~g} / \mathrm{kg} \text { seed, } \\
\text { Streptocyclin } 200 \mathrm{ppm} \text { and biofertilizers }\end{array}$ \\
\hline $\begin{array}{l}\text { Fertilizer } \\
\text { management }\end{array}$ & Use of DAP (50 kg/ha) & $15-20 \mathrm{~kg} \mathrm{~N} \& 30-40 \mathrm{~kg} \mathrm{P}_{2} \mathrm{O}_{5}$ \\
\hline Sowing method & Broadcasting & Line showing $(30 \mathrm{~cm} \times 10 \mathrm{~cm})$ \\
\hline Weed management & One hand hoeing at 20-25 DAS & $\begin{array}{l}\text { Use of Pendimethalin @ } 500 \mathrm{~g} \text { a.i./ha at } 1-2 \text { DAS } \\
\text { and Imazethapyr } 50 \mathrm{~g} \text { a.i. /ha at } 20-25 \mathrm{DAS}\end{array}$ \\
\hline Plant protection & $\begin{array}{l}\text { Use of monocrotophos and } \\
\text { quinalphos }\end{array}$ & $\begin{array}{l}\text { Application of imidacloprid17.8\% SL @ } 300 \mathrm{ml} / \mathrm{ha} \\
\text { for sucking pest control and Streptocyclin } 0.02 \% \text { or } \\
\text { COC } 0.3 \% \text { for bacterial blight. }\end{array}$ \\
\hline
\end{tabular}


Table.2 Yield performance, technology gap, extension gap and technology Index of clusterbean under Farmers' Practice and Front Line Demonstration

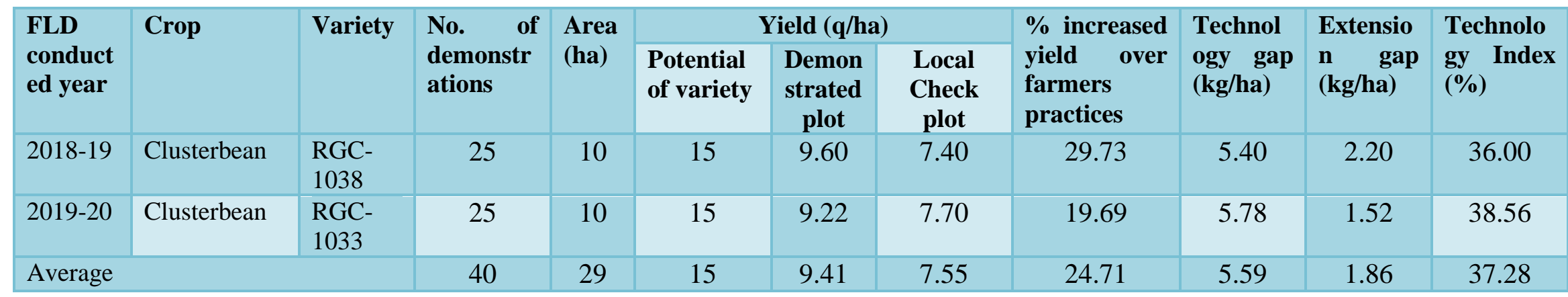

Table.3 Economics of clusterbean under front line demonstration

\begin{tabular}{|c|c|c|c|c|c|c|c|c|}
\hline \multirow{2}{*}{$\begin{array}{c}\text { Conducted } \\
\text { year }\end{array}$} & \multicolumn{2}{|c|}{ Cost of cultivation (Rs/ha) } & \multicolumn{2}{|c|}{ Gross returns (Rs/ha) } & \multicolumn{2}{|c|}{ Net Returns (Rs/ha) } & \multicolumn{2}{|c|}{ BC Ratio } \\
\hline & $\begin{array}{c}\text { Demonstrated } \\
\text { plot }\end{array}$ & $\begin{array}{c}\text { Local } \\
\text { Check plot }\end{array}$ & $\begin{array}{c}\text { Demonstrated } \\
\text { plot }\end{array}$ & $\begin{array}{c}\text { Local } \\
\text { Check plot }\end{array}$ & $\begin{array}{c}\text { Demonstrated } \\
\text { plot }\end{array}$ & $\begin{array}{c}\text { Local Check } \\
\text { plot }\end{array}$ & $\begin{array}{c}\text { Demonstrated } \\
\text { plot }\end{array}$ & $\begin{array}{c}\text { Local Check } \\
\text { plot }\end{array}$ \\
\hline 2018-19 & 19300 & 18500 & 40200 & 31300 & 20900 & 12800 & 2.08 & 1.69 \\
\hline $2019-20$ & 21272 & 20800 & 53746 & 46320 & 32474 & 25520 & 2.53 & 2.23 \\
\hline Average & 20286 & 19650 & 46973 & 38810 & 26687 & 19160 & 2.30 & 1.96 \\
\hline
\end{tabular}


It is concluded that the FLD programme is an effective tool for increasing the production and productivity of clusterbean and changing the knowledge, attitude and skill of farmers. The per cent increment in yield of clusterbean to the extent of 19.69 to 29.74 over the farmers practice created greater awareness and motivated the other farmers to adopt the improved package of practices of pulses. These demonstrations also built the relationship and confidence between farmers and scientists. The partner farmers of FLDs also play an important role as source of information and quality seeds for wider dissemination of the high yielding varieties of clusterbean for other nearby farmers.

\section{References}

Agricultural Statistics at a Glance 2018. Directorate of Economics and Statistics. Area, production and yield along with coverage under irrigation, pp-131.

Kherawat, B.S., Munna lal, Agarwal, M., Yadav, H.K. and Kumar, S. (2013). Effect of applied potassium and manganese on yield and uptake of nutrients by cluster bean (Cyanosis tetragonoloba). Journal of Agricultural Physics, 13(1): 22-26.

Patil, L.M., Modi, D.J., Vasava, H.M. and Gomkale, S.R. (2015). Evaluation of front line demonstration programme on green gram variety Meha (IPM-99-125) in Bharuch district of Gujarat. IOSR Journal of Agriculture and Veterinary Science, 8(9): 01-03.

Sahare, K.V., Tiwari, B.K., Tiwari, K.P., Singh, R.R., Baghel, K.S. and Singh, S. 2018. Performance of frontline demonstrations on productivity and profitability of black gram (Vigna mungo) through improved technologies under rainfed conditions. International Journal of Current Microbiology and Applied Sciences, 7 (10): 2319-7706.

Samui, S.K., Maitra, S., Roy, D.K., Mondal, A.K. and Saha, D. (2000). Evaluation on front line demonstration on groundnut (Arachis hypogea L.). Journal of the Indian Society of Coastal Agricultural Research, 18: 180-183.

\section{How to cite this article:}

Sumitra Devi Bamboriya, Gopichand Singh, Arjun Singh Jat and Ishwar Singh, S. 2020. Evaluation of Front Line Demonstration Trials on Clusterbean in Nagaur District of Rajasthan, India. Int.J.Curr.Microbiol.App.Sci. 9(01): 1909-1913. doi: https://doi.org/10.20546/ijcmas.2020.901.213 